\title{
World Petroleum Congress
}

TrHe E first World Petroleum Congress since the War was held in London on July 19-25 inclusive. Delegates from twenty-five countries attended and 1,200 members from all parts of the world took part in the proceedings. Members were welcomed by the president, Mr. T. Dewhurst, at the Science Museum, South Kensington, on the evening of July 19, and on the following day the work of the Congress began. Apart from the daily sessions, lectures were given at the Royal Institution by $\mathrm{Mr}$. J. B. Aug. Kessler on "Rationalisation of the Oil Industry" on July 20, a résumé of which follows this article, and by Sir John Cadman on "Science in the Petroleum Industry", referred to in Nature of July 29 , p. 162.

H.M. Government held a reception at Lancaster House on July 20 after Mr. Kessler's lecture, delegates and members being received by the President of the Board of Trade. Other social functions, also visits to various relevant industrial works, were arranged during the Congress period.

The Congress was divided into three main sections : geological ; production; and refining, chemical and testing. The Geological Section was concerned at first with the significance and the fundamental principles governing regional distribution of oilfields. Later, problems of actual oilfield developments were discussed. In this connexion consideration was given to unit development, well spacing, electric logging, methods of increasing oil recovery, evidence provided by coring, flush sampling, etc., and to general development schemes involving gas conservation, edge water control, group production, etc. Finally, recent developments in geological exploration were considered and the value of geophysical surveying, aerial photography and current field methods assessed.

The Production Section began its sessions with a survey of modern methods of drilling under various conditions. Later, transport and storage of oil were debated and theories advanced for protection and construction of pipe-lines. Further sessions were devoted to actual production methods as now practised in various parts of the world, and their relationship to reservoir conditions. The most effective rate of production and methods of control of flowing wells were discussed. Finally, a joint session was held with the Refining, Chemical and Testing Section, to consider measurement of oil in bulk.

Hydrogenation, which was brought before members of the Refining, Chemical and Testing Section, naturally attracted much attention in view of the recent declaration of policy in this matter by H.M. Government. Dr. Bergius opened the meetings with a historical account of hydrogenation and described some of the experiments he carried out some twenty years ago, when the subject was first mooted. Mr. Gordon, of Imperial Chemical Industries, Ltd., explained briefly the plant to be erected at Billinghamon-Tees for experimental production of liquid fuel from coal ; reference has already been made to this subject in NATURE of July $29, \mathrm{p} .160$. The scope of this section was extremely wide and included discussions on bituminous emulsions, the determination of gum in gasoline, viscosity and its expression, the desirable characteristics of fuels for high-speed compression engines, also problems connected with kerosene, lubricating oil, refining of cracked gasolines, oil-coal fuels, knock-rating, alternative fuels and, finally, a session was allotted to the study of petroleum as a chemical raw material, an extremely vital aspect of the modern technology.

The business of the Congress was concluded by a joint meeting of all sections, the main issue being international co-operation and standardisation. Emphasis was laid on the lack of accepted international nomenclature for petroleum and petroleum products and the need for co-operation between all existing national and international standardisation bodies. It was urged that the first step towards achievement of international terminology and complete standardisation of methods of test was to secure co-ordination of opinions among the various individual bodies in the countries concerned. The next stage was to appoint regular channels through which information could be readily disseminated and interchanged by the different countries. It was proposed and carried at the meeting that, in order to avoid overlapping and duplication of work, national petroleum nomenclature and methods of test should be arranged through the medium of an international body, namely, through Committee 28 of the International Standards Association.

It was generally felt that the Congress had fulfilled its purpose by bringing together specialists in all branches of the industry and by affording oppor. tunity for open discussion of the many salient problems arising from the rapid technical, scientific and commercial development of the industry during recent years. It was therefore proposed and unanimously carried that a World Petroleum Congress should be held triennially in order to further the constructive work of this 1933 Congress.

\section{Rationalisation of the Oil Industry}

$\mathrm{I}^{\mathrm{N}}$ his lecture on "Rationalisation of the Oil Industry" delivered to members of the World Petroleum Congress on July 21, Mr. J. B. Aug. Kessler contended that the lack of balance between production and consumption of each individual main product in the petroleum range is largely responsible for the present depressed state of the industry. Hitherto, the abnormally low prices prevailing for gasoline and fuel oil have been attributed generally to over-production of crude oil and to a systematic decrease in the consumption of its products. During the past few years, conservation of crude oil has been rigorously adopted as a corrective measure against these two major evils, but the fact remains that, although the consumption of petroleum products as a whole has exceeded the production, prices have fallen rapidly.

Primarily, crude oil is produced to meet the world's demand for gasoline. All other derivatives, therefore, must necessarily be regarded as byproducts, and of these fuel oil is by far the most important. 